The Kosciuszko Foundation Philadelphia Chapter

Newsletter No.20

View this email in your browser

\title{
Quo Vadis
}

Newsletter of the KF Philly Chapter

October 2019 • Issue No. 20

\section{Special Edition}

\section{Captivating still largely unknown story depicting the consequences of Pilecki's assumed identity plus how he was hidden and nursed to health after his escape from Auschwitz}

\section{By Elizabeth M. Zechenter}

In anticipation of the upcoming lecture on Witold Pilecki (October 20th, 2019, see below), Kosciuszko Foundation Philadelphia Chapter would like to invite you to read this special edition of Quo Vadis in which Elizabeth Zechenter, our own Chapter board member, has written a very personal account of a still largely unknown episode in Pilecki's life. It is a fascinating and spellbinding story, story of many coincidences and unusual twists, maybe even a story of true fate, as both Pilecki and Serafiński saw it. The article is richly illustrated and we hope, it will allow the reader to better understand how these three courageous people met and struggled for the liberation of Poland.

Elizabeth's family had a close connection to Witold Pilecki as her aunt and uncle Tomasz and Ludmiła Serafiński, both active in AK, provided hiding for Pilecki 


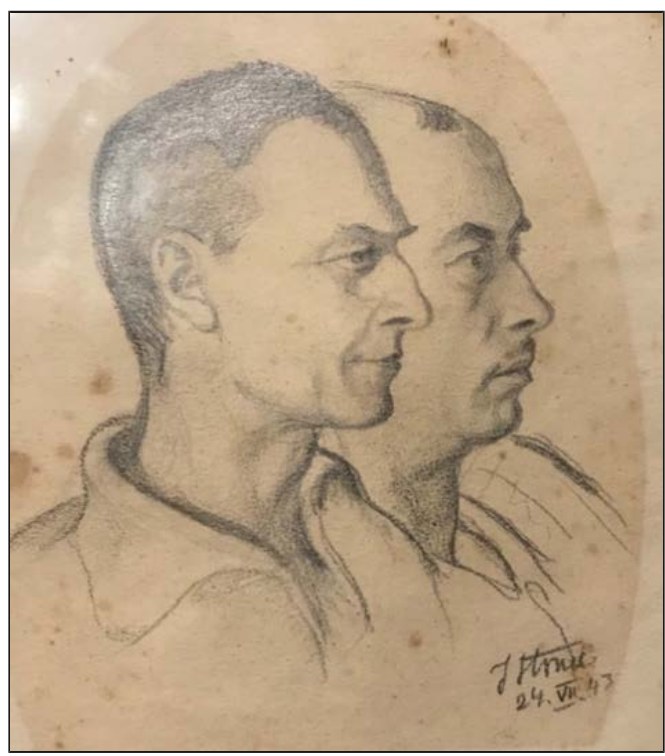

during the first three and half months after his escape from Auschwitz in their home called Koryznówka. They also tried to save his life after he was arrested and tried. Ultimately, all these three people paid a heavy price for their efforts to bring freedom to Poland and to stop Nazi atrocities: Pilecki was executed, Tomasz Serafiński was tortured and crippled for life, while Ludmiła, despite her daring efforts, was left alone with a burden of caring for two small children and a gravely ill husband.

[Above: Charcoal double portrait of "Two Serafińskis" by Jan Stasiniewicz dated 24 June 1943.

Below: Back of the double portrait signed by Witold Pilecki as "Witold Tomasz Serafiński" and by Tomasz Serafiński as himself. Dated 21 July 1943; below are written dates of Pilecki's Auschwitz imprisonment from September 19, 1940 until April 26, 1943. (Photos: author)]

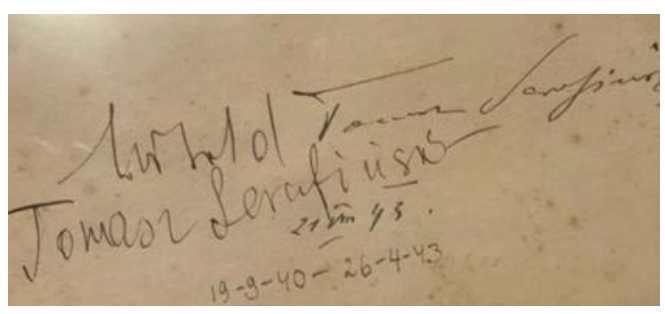

The entanglement between Witold Pilecki and Tomasz Serafiński started by what can be seen as an accident.

\section{Lieutenant Tomasz Serafiński}

(underground code name "Lis" and "Lisola") was active in the Polish underground in the Nowy Wiśnicz region and headed up the local regional unit of AK, as the commanding officer of the outpost "Sum." His wife Ludmiła (underground code name "Malwa") was also active in the underground and was the commanding officer of the women medical aid platoon operating in the Nowy Wiśnicz area. Tomasz and Ludmiła Serafiński owned a small family estate called Koryznówka near the town of Nowy Wiśnicz.

At some point in the Fall of 1939, Pilecki was hiding at the house of Dr. Helena Pawłowska, where previously Tomasz Serafiński was hiding, after the fall of Warsaw. Serafin'ski was wounded during the defense of Warsaw and after the fall of the city, was briefly recovering at Dr. Pawłowska's house. When leaving her house, Serafiński forgot some of his documents and Pilecki found them when he later arrived at Dr. Pawłowska's house. Pilecki, in need of a new underground identity and papers decided to take on the name and the identity of Tomasz Serafiński and obtained necessary identity documents in that name. Pilecki used the Serafinski name and identity when he allowed himself to be arrested during the German "round-up" on the night of 21st of September 1940 and he used that name during his entire time in Auschwitz, he used it even after 
his escape from Auschwitz in April 1943.

After his escape from Auschwitz, Pilecki and his two co-conspirators decided to travel to city of Bochnia because one of them had family in Bochnia. Pilecki appeared to be unaware of the fact that the real Tomasz Serafinski was alive, active in the underground and heading up the Nowy Wiśnicz unit of AK, only 7 $\mathrm{km}$ away from the town of Bochnia. Pilecki requested to be connected to the local AK command and, via another coincidence, the local AK member took Pilecki to Koryznówka. That is when the two men met for the first time and that is when Serafiński agreed to hide Pilecki. Pilecki stayed in Koryznówka for over three and half months during which time the two men became close.

At the time, there was a lot of confusion as to whether Pilecki and his coescapees were actually working for the Polish underground or whether they were German spies and provocateurs instead. Serafiński believed Pilecki and his story, unlike other local AK commanders. In fact, AK headquarters in Krakow issued an order for Tomasz Serafinski to break all contacts with Pilecki and his two co-escapees, an order which Tomasz Serafiński refused to carry out.

While recovering, Pilecki and his co-escapees were busy writing reports to document the German atrocities. The first report was written in June and the second in August of 1943. Most importantly, Pilecki was trying to make contacts with other underground units to prepare the liberation of the Auschwitz concentration camp. Tomasz Serafiński was instrumental in bringing heads of various other underground AK units as well as various Polish political organizations to meet Pilecki; several such meetings took place in Koryznówka during the three and half months of Pilecki's stay there. During their stay in Koryznówka, once they recovered, all four men - Pilecki, Redzej, Ciesielski and Tomasz Serafiński took an active part in, or provided support to various sabotage actions in the Nowy Wiśnicz-Bochnia area.

Meanwhile, Gestapo was actively searching for the escapees and sent out the arrest warrant for all three escapees. While Tomasz Serafiński managed to save Witold Pilecki (who equipped with a new identity and new falsified documents was able to leave Koryznówka for Warsaw on the 23rd of August 1943), Tomasz Serafiński was ultimately captured by the Gestapo on Christmas Day in 1943 as the "escapee from Auschwitz." He was tortured, both of his hands were broken repeatedly, he was severely beaten and lost his teeth, he repeatedly lost consciousness during the interrogation sessions so they placed him unconscious in an ice-cold cell with standing water. After several days of torture in a Bochnian jail, he was transferred to the Montelupi jail in Krakow, for more interrogations and torture. But for the rescue actions of his wife, Ludmiła, he would have died.

It was in Koryznówka were Pilecki wrote his initial reports documenting in detail Nazi atrocities committed in the concentration 


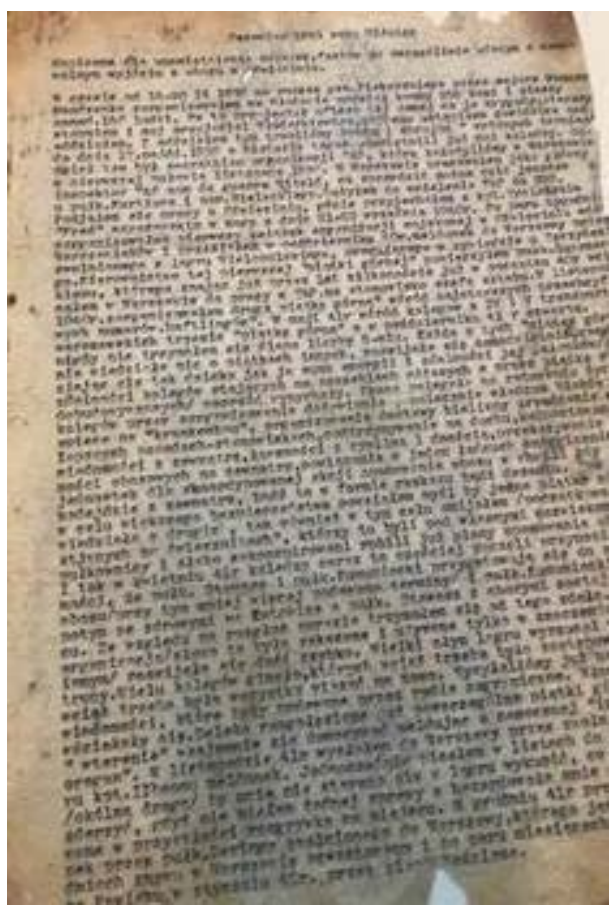

camps. The back-up copies of the reports were buried in the forest belonging to Koryznówka, they survived the war and remained in the possession of the Serafinski family. Elizabeth's aunt, Maria SerafińskaDomanski, donated the two Pilecki's reports written and buried for safekeeping in Koryznówka, to the AK Museum in Krakow in the 1990s.

Today, Koryznówka still remembers Pilecki. There is a memorial dedicated to Pilecki placed in the front garden and the photos of Pilecki and his co-escapees made in 1943 are still there. Pilecki's original drawings, as well as an oil portrait of Pilecki painted by a neighbor, Serafiński family close friend and also Polish underground member, Jan Stasiniewicz, were donated by Ludmiła Serafińska to Captain Pilecki's two children. One of the remaining photos shows Pilecki in front of Koryznówka, another shows all three escapees, Pilecki, Redzej, and Ciesielski, in white clean shirts standing in front of the Koryznówka on a sunny day. Until very recently, the double portrait of Tomasz Serafiński and Witold Pilecki (the so-called "Two Serafin'skis" portrait) was in the possession of Elizabeth's aunt. It has recently been transferred to the Auschwitz Museum and now all who visit Auschwitz will be able to see it too. As the director of the Auschwitz Museum, Dr. Piotr Cywiński, remarked during the recent ceremony:

"this sketch is something more than only a document as it has great emotional value. On one page of the paper, you have a portrait of two people connected by fate, love of the country and patriotism. That is why I am deeply grateful to the family for their decision to transfer this portrait. It will be not only kept protected here but we will make it available for all to see. It is one of the very few mementos left after Captain Pilecki.
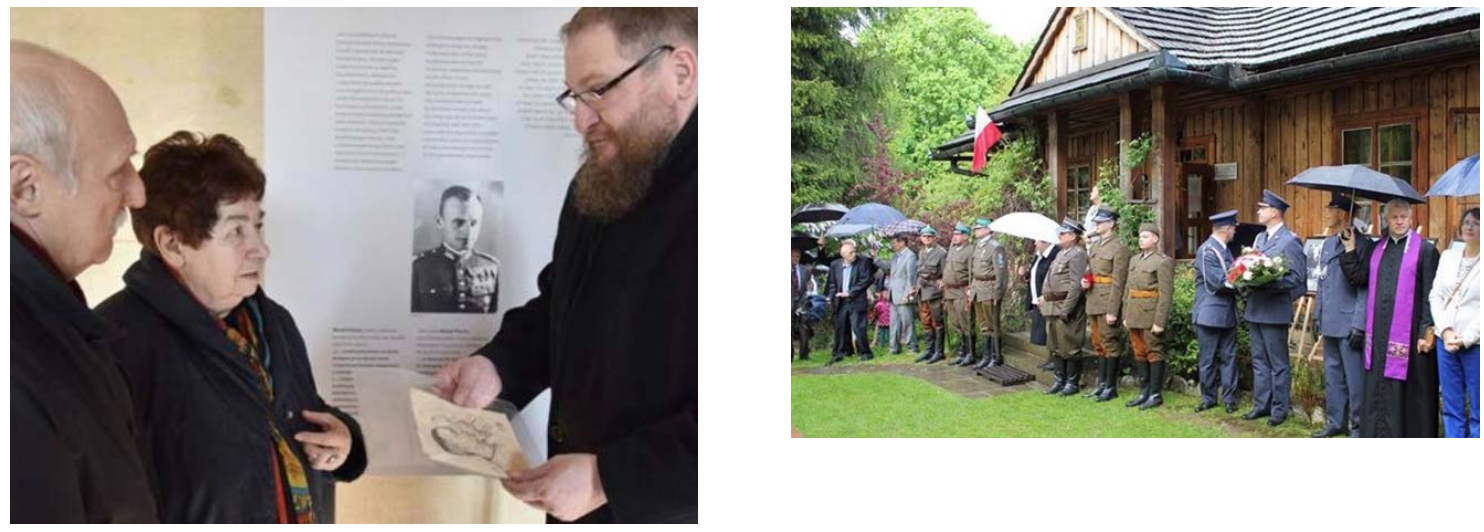
[Left: LMaria Serafin'ska -Domańska and her husband Stanisław Domański during the transfer ceremony of the "Two Serafin'skis" portrait, with the director of the Auschwitz Museum, Dr. Piotr Cywiński. Photo by Bartosz Bartyzel https://www.tvp.info/41112015/rysunek-przedstawiajacy-min-rotmistrza-pileckiego-trafildo-muzeum-auschwitz. Photo used with the permission of the Auschwitz Museum. Right: Annual Cavalry Ride honoring Pilecki being received in Koryznówka (Photo: Family archives)]

To read more of this fascinating story, please see the link to: "Was it Really a Blind Fate? Interwoven Lives of Witold Pilecki and Tomasz Serafin'ski and the Daring Efforts of Ludmiła Serafin'ska to Save Them Both" by Elizabeth M. Zechenter.

\section{Lecture and Book signing by Jack Fairweather, the author of "The Volunteer"}

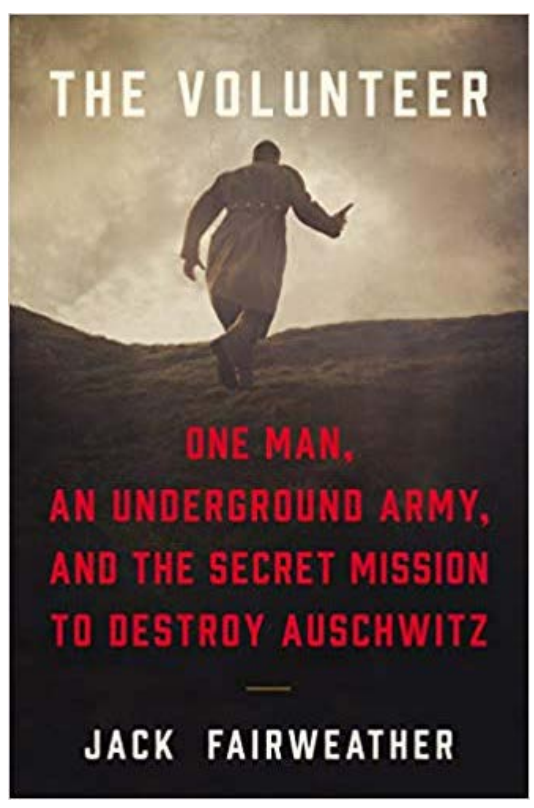

on Sunday, October 20th at 5:00 p.m. at The Associated Polish Home of Philadelphia 9150 Academy Road Philadelphia, PA 19114

(215) 624-9954

polishhome@gmail.com

Th is is the incredible true story of a Polish resistance fighter's infiltration of Auschwitz to sabotage the camp from within, and his deathdefying attempt to warn the Allies about the Nazis' plans for a "Final Solution."

Completely erased from the historical record by Poland's post-war Communist government, Pilecki remains almost unknown to the world. Now, with exclusive access to previously hidden diaries, family and camp survivor's accounts, and recently declassified files, Jack Fairweather offers an unflinching portrayal of survival, revenge, and betrayal in mankind's darkest hour. In uncovering the tragic outcome of Pilecki's mission, he reveals that its ultimate defeat originated not in Auschwitz or Berlin, but in London and Washington.

\section{Call for Contributions and Contributors}

Our newsletter welcomes contributions, comments, and news from our 
members and friends, as well as from collaborating organizations. Please consider writing a short article for our newsletter on any subject related to Polish culture. Send contributions to:

Margaret Zaleska: margaret.m.zaleska@gmail.com or Agnieszka Gerwel: dreamceramics@yahoo.com Learn more about our recent and past events here.

\section{Like us on Facebook}

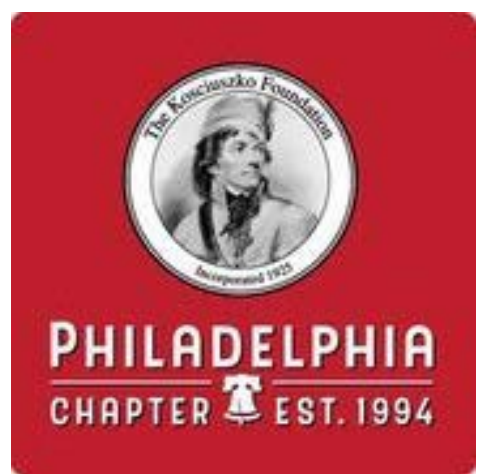

\section{Join the Kościuszko Foundation!}

For more information about the KF Philadelphia Chapter, or if you would like to become a Kościuszko Foundation member and join us on our celebration of all things Polish, please visit the website: https://www.thekf.org/kf/chapters/philadelphia/membership/. We warmly welcome you!

\section{The KF Philadelphia Chapter Board}




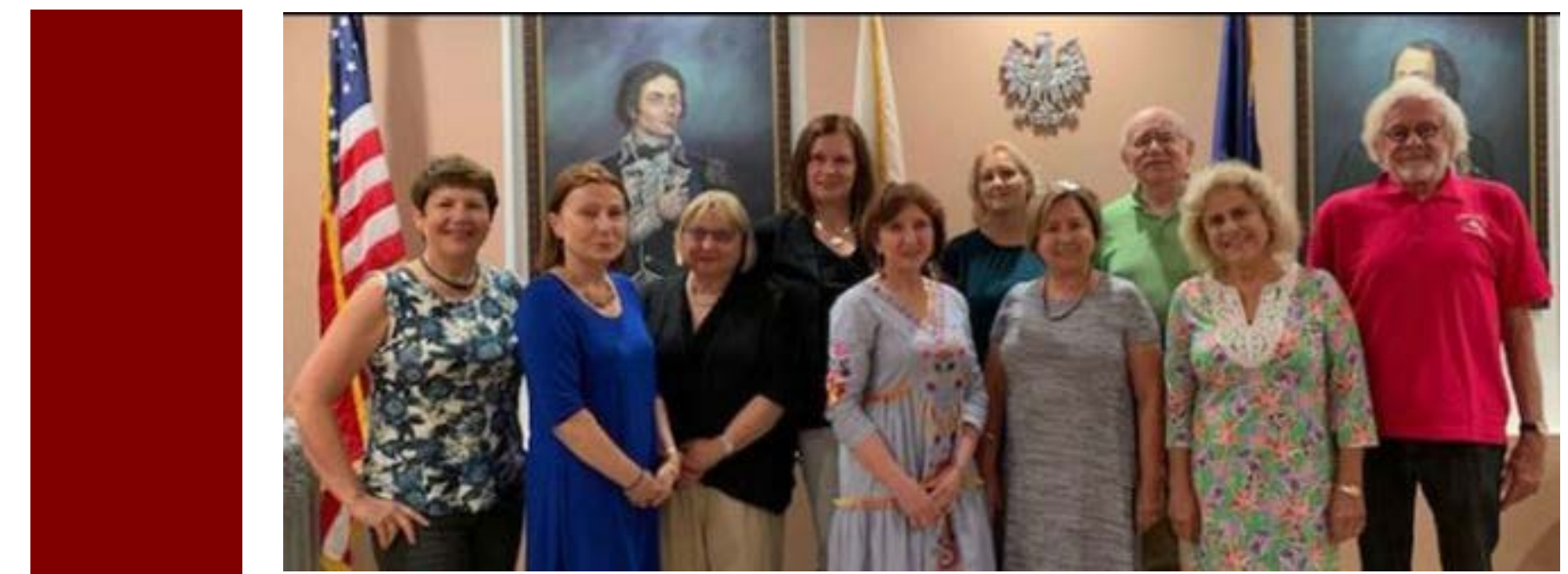

Board photo as of June 2019

\author{
Sylwia Czajkowska \\ President \\ Margaret Zaleska \\ Vice President \\ Peter Obst \\ Vice President
Hanna Wewiora
Treasurer \\ Ela Gosek \\ Secretary
}

\section{Directors:}

\section{Bozena Korczak}

Maria Werner -Wasik

Elizabeth Zechenter

Andre Zlotnicki

\section{Quo Vadis Editors:}

Margaret Zaleska

Agnieszka Gerwel

Copyright (c) 2019 The Philadelphia Chapter of the Kosciuszko Foundation, All rights reserved.

Contact us at:

thekfphiladelphia@gmail.com

Want to change how you receive these emails?

You can update your preferences or unsubscribe from this list 
This email was sent to $\leq<$ Email Address $>>$

why did I get this? unsubscribe from this list update subscription preferences

The Kosciuszko Foundation Philadelphia Chapter · 15 E 65th Street · New York, NY 10065 · USA

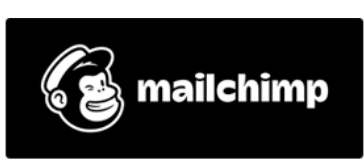

